\title{
Identifikasi Kandidat Microservies Dengan Analisis Domain Driven Design
}

\author{
I Wayan Adi Juliawan Pawana ${ }^{1}$, Dewa Made Wiharta ${ }^{2}$, Nyoman Putra Sastra $^{3}$ \\ [Submission: 04-06-2021, Accepted: 13-08-2021]
}

\begin{abstract}
The ongoing digital transformation requires organization not only to focus on business domains but also on their application landscapes. A more flexible architecture is need such as microservices architecture. Migration Lecturer Information System (SIMDOSEN) at Udayana University which was developed with monolithic architecture to microservices architecture raise a challenge of splitting business domain into distributed services. Domain Driven Design analysis is used to identify candidates for RESTful API-based microservices by splitting business capabilities. The results show a systematic and comprehensible process of developing microservice architecture. As well as having a positive impact on the advancement of IT architecture at Udayana University.
\end{abstract}

Keywords: Domain Driven Design, Microservices, Monolithic, RESTful API, SIMDOSEN.

Intisari- Transformasi digital yang sedang berlangsung menuntut organisasi tidak hanya berfokus pada domain bisnis, tetapi juga pada arsitektur aplikasi. Sehingga dibutuhkan arsitektur yang lebih fleksibel seperti arsitektur microservices. Migrasi Sistem Informasi Dosen (SIMDOSEN) pada Universitas Udayana yang dikembangkan dengan arsitektur monolithic menuju arsitektur microservices memunculkan tantangan untuk memisahkan domain bisnis menjadi layanan yang terdistribusi. Analisis Domain Driven Design digunakan untuk mengidentifikasi kandidat microservices berbasis RESTful API dengan memecah kemampuan bisnis. Hasil yang diperoleh menunjukkan proses pengembangan microservices yang sistematis dan dapat dipahami. Serta memberikan dampak positif untuk kemajuan arsitektur IT pada Universitas Udayana.

Kata Kunci-Domain Driven Design, Microservices, Monolithic, RESTfUL API, SIMDOSEN.

\section{PENDAHULUAN}

Sistem informasi pada umumnya dibangun menggunakan arsitektur monolithic yang-dikembangkan dalam satu entitas besar. Teknik ini membuat pengembangan awal menjadi sederhana dan mudah dimengerti [1].

Permasalahan pada arsitektur monolithic muncul ketika codebase mulai berkembang menjadi suatu aplikasi yang besar,

\footnotetext{
${ }^{1}$ Mahasiswa, Magister Teknik Elektro Universitas Udayana, Jalan Gelogor Indah 1B Gang Bisma No 17, Denpasar, 80221, Indonesia (tlp: 085-857162018; e-mail: adijuliawanpawana@unud.ac.id)

${ }^{2,3}$ Dosen, Jurusan Teknik Elektro dan Komputer Fakultas Teknik Universitas Udayana, Jln. Jalan Kampus Bukit Jimbaran 80361 INDONESIA (telp: 0361-703315; fax: 0361-4321; e-mail: wiharta@unud.ac.id,putra.sastra@unud.ac.id)
}

baik dari sisi ukuran file maupun jumlah data yang terlibat. Masalah utama tersebut adalah ketika codebase membesar, pengembangan sistem menjadi lebih lambat pada saat terdapat perubahan kebutuhan sistem, serta kesulitan untuk mengelola codebase dan terbatasnya opsi untuk scaling aplikasi dan ketegantungan yang tinggi antar modul [1],[2],[3].

Solusi terhadap permasalahan yang muncul pada arsitektur monolithic adalah suatu arsitektur yang dikenal dengan nama microservices. Arsitektur microservice adalah style arsitektur terbaru yang telah berkembang pada beberapa tahun terakhir. Tidak ada definisi pasti mengenai arsitektur microservice. Namun dapat dikatakan bahwa microservice adalah koleksi dari beberapa service kecil yang otonom [4]. Tiap service memiliki tugas masing-masing yang memenuhi single responsibility principle. Tiap service mampu untuk didistribusikan secara independent pada platfom yang berbeda dan berjalan pada lingkungan tersendiri dengan saling berkomunikasi mengunakan mekanisme komunikasi ringan, contohnya RESTful API [6],[10]. Dengan arsitektur microservice, suatu sistem informasi akan memiliki beberapa service yang dikelola dan didistribusikan secara independent sehingga kemampuan sistem untuk beradapatasi terhadap perubahan kebutuhan akan semakin mudah [5],[8].

Implementasi arsitektur microservice akan menyebabkan ada banyak services sehingga membutuhkan suatu standar dan dokumentasi untuk mengelola services tersebut [9]. The OpenAPI Specification (OAS) mendefinisikan standar, antarmuka dengan bahasa agnostik pada RESTful API.

Pada pemrograman komputer, bahasa agnostik mempunyai pengertian bahwa program dapat menerima data dalam berbagai format, atau dari berbagai sumber, dan masih bisa memproses data tersebut secara efektif. Dengan demikian, manusia dan komputer akan bisa saling mengetahui dan mengerti kemampuan dari service tanpa harus mengakses source code, dokumentasi atau melakukan inspeksi trafik jaringan [7]. Ketika didefinsikan secara detail, konsumen dapat mengerti dan berinteraksi dengan service dengan kebutuhan implementasi yang minim.

SIMDOSEN adalah salah satu aplikasi yang digunakan oleh tenaga pendidik di Universitas Udayana untuk memanajemen data pribadi dosen, kegiatan tridharma perguruan tinggi, riwayat, sasaran kerja pegawai (SKP) dosen, dan remunerasi. SIMDOSEN pada pengembangan awal didesain menggunakan arsitektur monolithic, menggunakan framework Codeigniter dan belum menggunakan RESTful service. Dalam perjalanannya, ditemukan beberapa permasalahan pada SIMDOSEN, antara lain:

- Untuk menambah fitur baru pada SIMDOSEN, diperlukan perubahan skema database yang akan berdampak kepada modul lain. Walaupun sudah

I W. A. J. Pawana: Identifikasi Kandidat Microservies Dengan. . .

p-ISSN:1693 - 2951; e-ISSN: 2503-2372

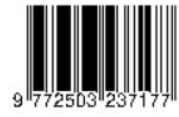


didesain dengan baik di awal, tetapi keterikatan antar modul masih tetap tinggi.

- Tidak adanya RESTful API service, sehingga sistem lain yang memerlukan data pada SIMDOSEN, akan dilakukan koneksi langsung pada database SIMDOSEN dan menjalankan suatu query. Hal ini mengakibatkan programmer sistem lain menjadi kesulitan karena harus mempelajari struktur database SIMDOSEN. Kesulitan pengembangan lebih tinggi lagi dengan tidak adanya dokumentasi sehingga integrasi sistem menjadi proses yang rumit di lingkungan Universitas Udayana.

- Penggunaan teknologi yang tidak bisa bebas. Pada SIMDOSEN terdapat beberapa kebutuhan yang belum bisa diakomodasi secara penuh serta fitur yang belum optimal, seperti pencarian dokumen penelitian dosen yang lebih optimal ketika menggunakan database NoSQL.

Solusi terhadap permasalahan tersebut adalah melakukan migrasi menuju arsitektur microservices. Karena aplikasi SIMDOSEN merupakan suatu aplikasi yang besar, dengan melibatkan banyak fungsi/modul dan melibatkan banyak data, proses migrasi ini akan menjadi suatu pekerjaan yang besar, Pada penelitian ini, dilakukan bagian awal dari proses migrasi dengan melakukan analisis arsitektur microservices pada SIMDOSEN dengan menggunakan analisis Domain Driven Design (DDD) [19],[22]. Dengan analisis DDD, akan bisa dilakukan identifikasi pada services yang dibutuhkan dalam proses migrasi tersebut. Secara keseluruhan, tujuan dari penelitian ini adalah untuk dapat meningkatkan kemampuan adaptasi SIMDOSEN terhadap perkembangan kebutuhan di masa mendatang.

SIMDOSEN mengelola data seluruh dosen Universitas Udayana mulai dari manajemen riwayat, pelaporan beban kerja dosen, perhitungan remunerasi dan manajemen karya ilmiah dosen. Banyaknya tanggung jawab yang menjadi beban dari sistem ini menyebabkan sistem sulit beradaptasi dengan kebutuhan yang dinamis. Model arsitektur microservices diharapkan akan mampu memberi efisiensi dan fleksibilitas dalam melakukan adaptasi terhadap perubahan kebutuhan yang cepat.

\section{TEORI PENUNJANG}

\section{A. Microservices}

Arsitektur Microservices adalah suatu pendekatan dalam pengembangan sebuah aplikasi sebagai suatu rangkaian service kecil, setiap service berjalan dengan proses sendiri dan berkomunikasi dengan suatu mekanisme ringan seperti HTTP API [22],[26]. Service tersebut dibuat berdasarkan kemampuan bisnis dan dapat diterapkan secara independen. Service dapat dibuat dengan bahasa pemrograman yang berbeda dan dapat menggunakan teknologi penyimpanan data yang berbeda [8].

Tujuan microservices adalah untuk menghasilkan unit-unit otonom yang terisolasi satu sama lain dan mengkoordinasikannya ke dalam suatu infrastruktur terdistribusi dengan teknologi container seperti Docker.
Umumnya, dengan mengadopsi model arsitektur ini akan berimplikasi pada menggunakan praktek agile seperti DevOps [21],[25] yang mengurangi waktu untuk mengimplementasi perubahan dari lingkungan development ke lingkungan production berbasis cloud. Dengan menggunakan teknologi cloud computing maka penggunaan resource $\mathrm{CPU}$ dan memory server akan lebih optimal [27].

\section{B. Domain Driven Design}

Domain Driven Design adalah suatu pendekatan pengembangan software yang berpusat pada pengembangan model domain yang memiliki pemahaman mengenai proses dan aturan dari suatu domain [23]. Sebuah model bertindak sebagai Ubiquitous Language untuk membantu komunikasi antara pengembang software dan ahli domain yang melakukan pemetaan domain. Model juga bertindak sebagai landasan konseptual untuk desain software itu sendiri, tentang bagaimana software dipecah menjadi object atau fungsi. Klasfikasi aktifitas model yang dihasilkan dari Domain Driven Design ke dalam proses pengembangan software dapat meningkatkan applicability [18].

Bounded Context (BC) adalah pola sentral dalam DomainDriven Design. BC adalah fokus dari bagian desain strategis DDD yang berhubungan dengan model dan tim pengembang yang besar. DDD berurusan dengan model-mocel yang besar dengan membaginya ke dalam $\mathrm{BC}$ yang berbeda dan menyatakan secara eksplisit tentang keterkaitan mereka [24].

\section{RESTful API}

RESTful API atau bisa disebut dengan REST API merupakan singkatan dari Representational State Transfer, merupakan abstraksi dari suatu arsitektur untuk sebuah Application Program Interface (API) yang menggunakan protokol HTTP untuk komunikasi data (antara sistem hypermedia terdistribusi), menggunakan konsep resource dengan setiap komponennya dianggap sebagai sebuah resource dan setiap resource diakses menggunakan HTTP Method seperti GET, POST, PUT, DELETE [11],[12].

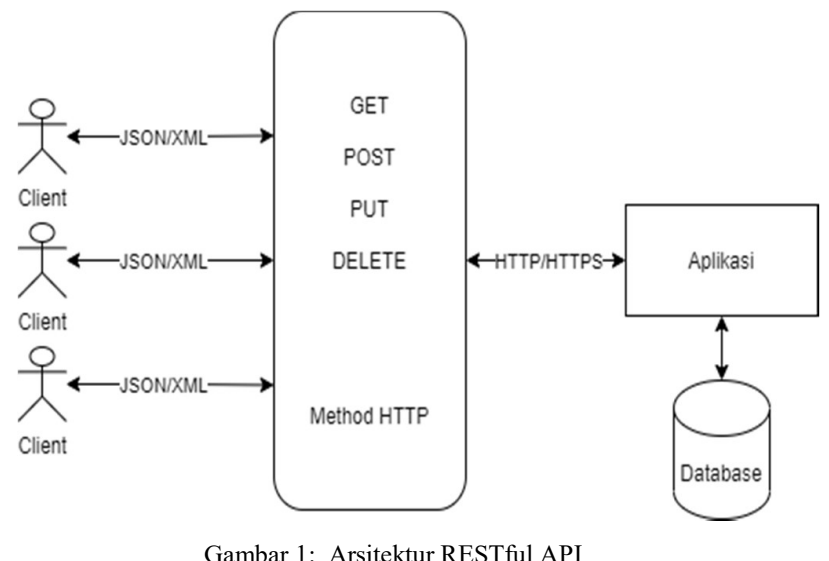

RESTful API adalah suatu style arsitektur dan bukan suatu bahasa pemrograman atau teknologi. Ini memberikan suatu panduan pada sistem terdistribusi untuk berkomunikasi secara 
Majalah Ilmiah Teknologi Elektro, Vol. 20, No.2, Juli-Desember 2021

DOI: https://doi.org/10.24843/MITE.2021.v20i02.P11

langsung menggunakan protokol web yang sudah ada untuk membuat suatu web services dan API, tanpa harus menggunakan protokol yang rumit [12]. Dari perspektif bisnis, RESTful API dapat dilihat sebagai aset berharga [14] yang dapat juga menjadi solusi transformasi digital [15].

Arsitektur RESTful API menyediakan akses ke resource sehingga client mengakses dan menampilkan hasil resource ke sisi client. RESTful API mengunakan beberapa format representasi untuk menampilkan hasil seperti XML, JSON, teks, dan gambar. Arsitektur umum RESTful API ditunjukkan pada Gambar 1.

\section{METODE PENELITIAN}

Susunan tahapan penelitiaan ditunjukkan pada Gambar 2, diawali dengan studi permasalahan, yaitu pada Sistem Informasi Dosen (SIMDOSEN) Universitas Udayana yang saat ini sedang berjalan. Tahapan berikutnya adalah studi literatur yang didapatkan dari berbagai sumber terkait arsitektur microservices, proses analisis microservice, RESTful API, dan lain-lain.

Tahapan pengumpulan data dilakukan dengan mencari data pada Sistem Informasi Dosen, petunjuk teknis, pentunjuk penggunaan, dan lain-lain. Tahapan berikutnya adalah analisis kondisi eksisting, yaitu analisis model arsitektur monolithic sistem informasi dosen yang sedang berjalan saat ini. Hasil analisis ini digunakan sebagai dasar untuk melakukan tahapan berikutnya, yaitu perancangan model arsitektur microservices. Tahapan terakhir adalah melakukan evaluasi hasil rancangan model arsitektur microservices.

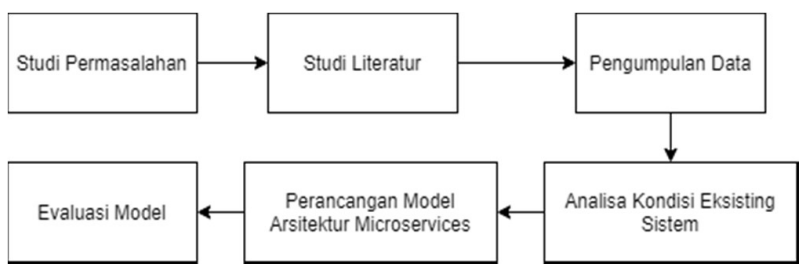

Gambar 2: Metodologi Penelitian

\section{HASIL IDENTIFIKASI KANDIDAT MICROSERVICES DENGAN ANALISIS DDD}

\section{A. Proses Decoupling Microservice (DDD)}

Proses migrasi sistem dari arsitektur monolithic menjadi arsitektur microservices bukan suatu pekerjaan biasa. Pada proses migrasi ini dilakukan pendekatan iteratif untuk memastikan kestabilan dari sistem. Hal ini dilakukan karena pada prosesnya dimungkinan muncul masalah seperti identifikasi yang tidak sesuai atau pemisahan tanggung jawab yang kurang tepat. Proses analisis sistem arsitektur monolithic dilakukan dengan metode Domain-Driven Design (DDD) [22] untuk mengekstrak kandidat microserices dari sistem asal. Tahap selanjutnya adalah mendesain API bedasarkan hasil kandidat microservices untuk kemudian disusun dokumentasi API menggunakan spesifikasi OpenAPI Specification 3.

I W. A. J. Pawana: Identifikasi Kandidat Microservies Dengan. . .
B. Analisis sistem untuk identifikasi kandidat microservices

Metode analisis yang digunakan untuk melakukan migrasi arsitektur monolithic ke arsitektur microservices adalah Doman Driven Design. Bounded Context (BC) dari hasil analisis menghasilkan kandidat untuk memecah services. Tidak ada acuan bagaimana memecah service, bisa berbeda-beda bergantung pada kebutuhan dari masing masing sistem, ukuran tim pengembang dan permintaan dari stakeholder [20]. Karakteristik dari DDD adalah sebagai berikut.

1) setiap project untuk suatu domain tertentu.

2) sistem yang kompleks terdiri dari kumpulan domain module.

3) masalah domain dianalisis oleh pengembang bersama dengan tim ahli.

Setiap microservices didesain sebagai komponen yang saling independent, dan hasil analisis dari DDD digunakan sebagai salah satu cara untuk mengekstrak service dengan domain spesifik.

Analisis berikutnya adalah analisis struktur database sistem monolithic. Ketika mengembangkan sistem monolithic maka akan ada dependensi tinggi (thightly coupling) antar modul. Pada arsitektur microservices tiap service memiliki database tersendiri yang terpisah antar service lain. Untuk tabel yang digunakan bersama akan dibuatkan service master untuk mengurangi dependensi dan keterikatan antar service. Hasil analisis domain model DDD ditunjukkan pada Gambar 3.

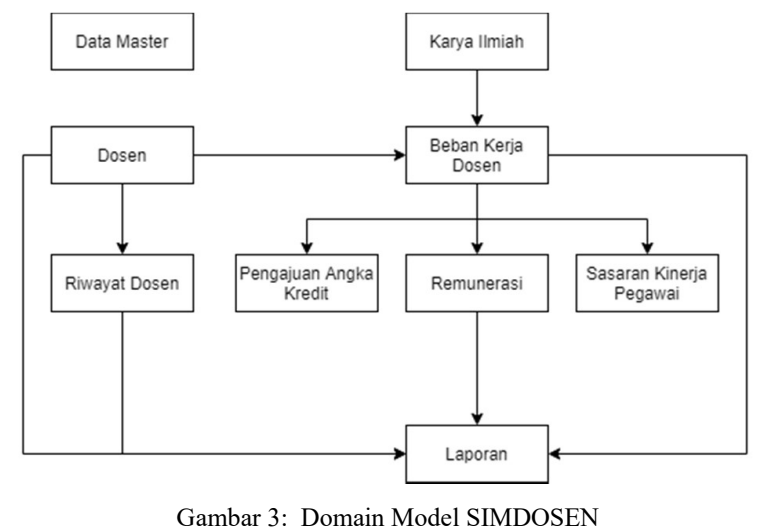

Pada kasus SIMDOSEN, dengan analisis DDD didapatkan kandidat service sebagai berikut: Service Data Dosen, Service Riwayat, Service BKD, Service Karya Ilmiah, Service Laporan, Service Pengajuan Angka Kredit (PAK), Service remunerasi, Service SKP, Service Data Master seperti ditunjukkan pada Gambar 4.

Service Data Dosen menyediakan data dosen dari masing masing pribadi dosen. Service ini juga memanggil service riwayat untuk mendapatkan data riwayat terakhir dosen. Service Riwayat menyediakan data riwayat dari dosen di lingkungan Universitas Udayana. Data riwayat yang disediakan adalah riwayat pendidikan, riwayat fungsional, riwayat jabatan, riwayat tugas tambahan, riwayat keaktifan, dan riwayat penugasan. Service BKD adalah layanan untuk dosen p-ISSN:1693 - 2951; e-ISSN: 2503-2372 
menginputkan dan melaporkan kegiatan tridarma perguruan tinggi seperti pendidikan, penelitian, pengabdian dan penunjang. Service karya ilmiah adalah layanan untuk dosen menginputkan penelitian yang pernah dikerjakan selama menjadi dosen. Service Pengajuan Angka Kredit adalah layanan untuk mengajukan kenaikan pangkat, dalam layanan ini dosen dapat menginputkan data kenaikan pangkat undur pendidikan, penelitian, pengabdian, dan penunjang. Service Remunerasi adalah layanan untuk menghitung dan menampilkan kinerja dari dosen. Service SKP adalah layanan untuk mengisi target dan realisasi sasaran kinerja pegawai. Service laporan adalah layanan untuk melihat laporan keseluruhan di sistem simdosen seperti laporan data dosen, laporan statistik BKD dan laporan statistik remunerasi. Service data master adalah layanan data master yang digunakan sebagai data master yang banyak diakses oleh banyak service seperti master tahun ajar, master unit, master sub unit dan master kegiatan BKD.

Uraian di atas secara umum digunakan untuk memetakan kandidat microservice yang ditunjukkan pada Gambar 4 dan Tabel 1 .

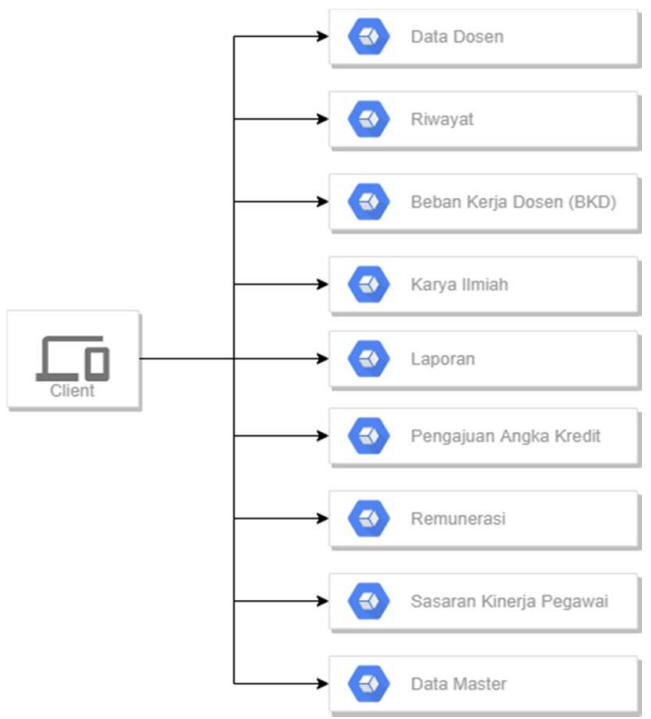

Gambar 4: Kandidat Service SIMDOSEN

TABEL I

MODULE DAN SERVICE PADA SIMDOSEN

\begin{tabular}{|c|l|l|}
\hline No & Modul & Services \\
\hline 1 & Data Dosen & Profil Dosen \\
\hline 2 & \multirow{2}{*}{ Riwayat } & Riwayat Pendidikan \\
\cline { 3 - 3 } & & Riwayat Fungsional \\
\cline { 3 - 3 } & & Riwayat Jabatan \\
\cline { 3 - 3 } & & Riwayat Tugas Tambahan \\
\cline { 3 - 3 } & & Riwayat Keaktifan \\
\hline 3 & \multirow{2}{*}{ BKD } & BKD Pendidikan \\
& & BKD Penelitian \\
\cline { 3 - 3 } & & BKD Pengabdan \\
\cline { 3 - 3 } & & BKD Penunjang \\
\cline { 3 - 3 } & & Pengajuan BKD \\
\hline 4 & Karya Ilmiah & Karya Ilmiah \\
\hline
\end{tabular}

\begin{tabular}{|c|c|c|}
\hline \multirow[t]{3}{*}{5} & \multirow[t]{3}{*}{ Laporan } & Laporan Data Dosen \\
\hline & & Laporan Statistik BKD \\
\hline & & Laporan Statistik Remunerasi \\
\hline \multirow[t]{4}{*}{6} & \multirow{4}{*}{$\begin{array}{l}\text { Pengajuan Angka } \\
\text { Kredit (PAK) }\end{array}$} & PAK Pendidikan \\
\hline & & PAK Penelitian \\
\hline & & PAK Pengabdian \\
\hline & & PAK Penunjang \\
\hline \multirow[t]{4}{*}{7} & \multirow[t]{4}{*}{ Remunerasi } & Remunerasi Gaji \\
\hline & & Remunerasi Kinerja \\
\hline & & Perhitungan Remunerasi Gaji \\
\hline & & Perhitungan Remunerasi Kinerja \\
\hline \multirow[t]{2}{*}{8} & \multirow[t]{2}{*}{ SKP } & Target SKP \\
\hline & & Realisasi SKP \\
\hline \multirow[t]{4}{*}{9} & \multirow[t]{4}{*}{ Data Master } & Master Tahun Ajar \\
\hline & & Master Unit \\
\hline & & Master Sub Unit \\
\hline & & Master Kegiatan BKD \\
\hline
\end{tabular}

Dengan melakukan analisis kebutuhan masing masing microservices, membaca source code sistem monolithic SIMDOSEN dan melakukan pengelompokan kandidat resource bedasarkan [16] maka dapat diidentifikasi kebutuhan API yang ditunjukkan pada Tabel II sampai Tabel X.

TABEL II

RANCANGAN MICROSERVICES DATA DOSEN

\begin{tabular}{|c|l|l|}
\hline No & URI & Method HTTP \\
\hline 1 & $/$ api/v1/dosen & GET, POST, \\
& & PUT, DELETE \\
\hline 2 & $/$ api/v1/dosen/ $\{$ dosenId $\}$ & GET, PUT, \\
& & DELETE \\
\hline
\end{tabular}

TABEL III

RANCANGAN MICROSERVICES RIWAYAT

\begin{tabular}{|c|l|l|}
\hline No & URI & Method HTTP \\
\hline 1 & /api/v1/riwayat-pendidikan & $\begin{array}{l}\text { GET, POST, } \\
\text { PUT, DELETE }\end{array}$ \\
\hline 2 & $\begin{array}{l}\text { /api/v1/riwayat- } \\
\text { pendidikan/\{riwayatPendidikanId }\}\end{array}$ & $\begin{array}{l}\text { GET, PUT, } \\
\text { DELETE }\end{array}$ \\
\hline 3 & $\begin{array}{l}\text { /api/v1/riwayat- } \\
\text { pendidikan/dosen }\{\text { dosenId }\}\end{array}$ & GET \\
\hline 4 & $\begin{array}{l}\text { /api/v1/riwayat- } \\
\text { pendidikan/dosen }\{\text { dosenId }\} / \text { latest }\end{array}$ & GET \\
\hline 5 & $\begin{array}{l}\text { /api/v1/riwayat-fungsional } \\
\text { fungsional/\{riwayatFungsionalId }\}\end{array}$ & $\begin{array}{l}\text { GET, POST, } \\
\text { PUT, DELETE }\end{array}$ \\
\hline 6 & $\begin{array}{l}\text { GET, PUT, } \\
\text { DELETE }\end{array}$ \\
\hline 7 & $\begin{array}{l}\text { /api/v1/riwayat- } \\
\text { fungsional/dosen }\{\text { dosenId }\}\end{array}$ & GET \\
\hline 8 & $\begin{array}{l}\text { /api/v1/riwayat- } \\
\text { fungsional/dosen }\{\text { dosenId }\} / \text { latest }\end{array}$ & GET \\
\hline 9 & $\begin{array}{l}\text { /api/v1/riwayat-kepangkatan } \\
\text { fiwat- }\end{array}$ & $\begin{array}{l}\text { GET, POST, } \\
\text { PUT, DELETE }\end{array}$ \\
\hline 10 & $\begin{array}{l}\text { /api/v1/riwayat-kepangkatan/ } \\
\text { \{riwayatKepangkatanId }\end{array}$ & $\begin{array}{l}\text { GET, PUT, } \\
\text { DELETE }\end{array}$ \\
\hline 11 & $\begin{array}{l}\text { /api/v1/riwayat- } \\
\text { kepangkatan/dosen }\{\text { dosenId }\}\end{array}$ & GET \\
\hline 12 & $\begin{array}{l}\text { /api/v1/riwayat- } \\
\text { kepangkatan/dosen }\{\text { dosenId }\} / \text { latest }\end{array}$ & GET \\
\hline
\end{tabular}


Majalah Ilmiah Teknologi Elektro, Vol. 20, No.2, Juli-Desember 2021

DOI: https://doi.org/10.24843/MITE.2021.v20i02.P11

\begin{tabular}{|c|c|c|}
\hline 13 & /api/v1/riwayat-keaktifan & $\begin{array}{l}\text { GET, POST, } \\
\text { PUT, DELETE }\end{array}$ \\
\hline 14 & $\begin{array}{l}\text { /api/v1/riwayat- } \\
\text { keaktifan/\{riwayatKeaktifanId\} }\end{array}$ & $\begin{array}{l}\text { GET, PUT, } \\
\text { DELETE }\end{array}$ \\
\hline 15 & $\begin{array}{l}\text { /api/v1/riwayat- } \\
\text { keaktifan/dosen }\{\text { dosenId }\}\end{array}$ & GET \\
\hline 16 & $\begin{array}{l}\text { /api/v1/riwayat- } \\
\text { keaktifan/dosen }\{\text { dosenId }\} / \text { latest }\end{array}$ & GET \\
\hline 17 & /api/v1/riwayat-tugas-tambahan & $\begin{array}{l}\text { GET, POST, } \\
\text { PUT, DELETE }\end{array}$ \\
\hline 18 & $\begin{array}{l}\text { /api/v1/riwayat-tugas- } \\
\text { tambahan/\{riwayatTugasTambahanId }\end{array}$ & $\begin{array}{l}\text { GET, PUT, } \\
\text { DELETE }\end{array}$ \\
\hline 19 & $\begin{array}{l}\text { /api/v1/riwayat-tugas- } \\
\text { tambahan/dosen }\{\text { dosenId }\end{array}$ & GET \\
\hline 20 & $\begin{array}{l}\text { /api/v1/riwayat-tugas- } \\
\text { tambahan/dosen }\{\text { dosenId }\} / \text { latest }\end{array}$ & GET \\
\hline 21 & /api/v1/riwayat-penugasan & $\begin{array}{l}\text { GET, POST, } \\
\text { PUT, DELETE }\end{array}$ \\
\hline 22 & $\begin{array}{l}\text { /api/v1/riwayat- } \\
\text { penugasan/\{riwayatPenugasanId }\end{array}$ & $\begin{array}{l}\text { GET, PUT, } \\
\text { DELETE }\end{array}$ \\
\hline 23 & $\begin{array}{l}\text { /api/v1/riwayat- } \\
\text { penugasan/dosen }\{\text { dosenId }\}\end{array}$ & GET \\
\hline 24 & $\begin{array}{l}\text { /api/v1/riwayat- } \\
\text { penugasan/dosen }\{\text { dosenId }\} / \text { latest }\end{array}$ & GET \\
\hline
\end{tabular}

TABEL IV

RANCANGAN MICROSERVICES BEBAN KERJA DOSEN

\begin{tabular}{|c|c|c|}
\hline No & URI & Method HTTP \\
\hline 1 & $\begin{array}{l}\text { /api/v1/bkd/identitas/dosen/ } \\
\text { \{dosenId } / \text { tahun-ajar/ \{tahunAjar\} }\end{array}$ & $\begin{array}{l}\text { GET, POST, } \\
\text { PUT, DELETE }\end{array}$ \\
\hline 2 & $\begin{array}{l}\text { /api/v1/bkd/pendidikan/dosen/ } \\
\{\text { dosenId } / \text { tahun-ajar/ }\{\text { tahunAjar }\}\end{array}$ & $\begin{array}{l}\text { GET, POST, } \\
\text { PUT, DELETE }\end{array}$ \\
\hline 3 & $\begin{array}{l}\text { /api/v1/bkd/pendidikan/dosen/ } \\
\{\text { dosenId }\} / \text { tahun-ajar/ }\{\text { tahunAjar }\} / \\
\text { id/ }\{\text { bkdPendidikanId }\}\end{array}$ & $\begin{array}{l}\text { GET, PUT, } \\
\text { DELETE }\end{array}$ \\
\hline 4 & $\begin{array}{l}\text { /api/v1/bkd/pendidikan/dosen/ } \\
\text { \{dosenId } / \text { tahun-ajar/ \{tahunAjar }\} \text { / } \\
\text { terpakai }\end{array}$ & GET \\
\hline 5 & $\begin{array}{l}\text { /api/v1/bkd/pendidikan/dosen/ } \\
\{\text { dosenId } / \text { tahun-ajar/ \{tahunAjar }\} / \\
\text { tidak-terpakai }\end{array}$ & GET \\
\hline 6 & $\begin{array}{l}\text { /api/v1/bkd/penelitian/dosen/ } \\
\{\text { dosenId } / \text { tahun-ajar/ }\{\text { tahunAjar }\}\end{array}$ & $\begin{array}{l}\text { GET, POST, } \\
\text { PUT, DELETE }\end{array}$ \\
\hline 7 & $\begin{array}{l}\text { /api/v1/bkd/penelitian/dosen/ } \\
\{\text { dosenId }\} / \text { tahun-ajar/ }\{\text { tahunAjar }\} / \\
\text { id/ }\{\text { bkdPenelitianId }\}\end{array}$ & $\begin{array}{l}\text { GET, PUT, } \\
\text { DELETE }\end{array}$ \\
\hline 8 & $\begin{array}{l}\text { /api/v1/bkd/penelitian/dosen/ } \\
\{\text { dosenId } / \text { tahun-ajar/ \{tahunAjar }\} / \\
\text { terpakai }\end{array}$ & GET \\
\hline 9 & $\begin{array}{l}\text { /api/v1/bkd/penelitian/dosen/ } \\
\{\text { dosenId }\} / \text { tahun-ajar/ }\{\text { tahunAjar }\} \text { / } \\
\text { tidak-terpakai }\end{array}$ & GET \\
\hline 10 & $\begin{array}{l}\text { /api/v1/bkd/pengabdian/dosen/ } \\
\{\text { dosenId } / \text { tahun-ajar/ }\{\text { tahunAjar }\}\end{array}$ & $\begin{array}{l}\text { GET, POST, } \\
\text { PUT, DELETE }\end{array}$ \\
\hline 11 & $\begin{array}{l}\text { /api/v1/bkd/pengabdian/dosen/ } \\
\text { \{dosenId }\} / \text { tahun-ajar/ \{tahunAjar }\} / \\
\text { id/ \{bkdPengabdianId }\}\end{array}$ & $\begin{array}{l}\text { GET, PUT, } \\
\text { DELETE }\end{array}$ \\
\hline
\end{tabular}

\begin{tabular}{|c|c|c|}
\hline 12 & $\begin{array}{l}\text { /api/v1/bkd/pengabdian/dosen/ } \\
\{\text { dosenId }\} / \text { tahun-ajar/ }\{\text { tahunAjar }\} / \\
\text { terpakai }\end{array}$ & GET \\
\hline 13 & $\begin{array}{l}\text { /api/v1/bkd/pengabdian/dosen/ } \\
\text { \{dosenId }\} \text { / tahun-ajar/ \{tahunAjar }\} \text { / } \\
\text { tidak-terpakai }\end{array}$ & GET \\
\hline 14 & $\begin{array}{l}\text { /api/v1/bkd/penunjang/dosen/ } \\
\{\text { dosenId } / \text { tahun-ajar/ }\{\text { tahunAjar }\}\end{array}$ & $\begin{array}{l}\text { GET, POST, } \\
\text { PUT, DELETE }\end{array}$ \\
\hline 15 & $\begin{array}{l}\text { /api/v1/bkd/penunjang/dosen/ } \\
\text { \{dosenId }\} / \text { tahun-ajar/ \{tahunAjar }\} \text { / } \\
\text { id/ \{bkdPendidikanId }\}\end{array}$ & $\begin{array}{l}\text { GET, PUT, } \\
\text { DELETE }\end{array}$ \\
\hline 16 & $\begin{array}{l}\text { /api/v1/bkd/penunjang/dosen/ } \\
\text { \{dosenId } / \text { tahun-ajar/ }\{\text { tahunAjar }\} / \\
\text { terpakai }\end{array}$ & GET \\
\hline 17 & $\begin{array}{l}\text { /api/v1/bkd/penunjang/dosen/ } \\
\text { \{dosenId } / \text { tahun-ajar/ \{tahunAjar }\} / \\
\text { tidak-terpakai }\end{array}$ & GET \\
\hline 18 & $\begin{array}{l}\text { /api/v1/bkd/penunjang/dosen/ } \\
\{\text { dosenId }\} / \text { tahun-ajar/ }\{\text { tahunAjar }\} / \\
\text { kesimpulan }\end{array}$ & $\begin{array}{l}\text { GET, POST, } \\
\text { PUT, DELETE }\end{array}$ \\
\hline 19 & $\begin{array}{l}\text { /api/v1/bkd/penunjang/dosen/ } \\
\{\text { dosenId }\} / \text { tahun-ajar/ \{tahunAjar }\} \\
\text { kesimpulan/pendidikan }\end{array}$ & GET \\
\hline 20 & $\begin{array}{l}\text { /api/v1/bkd/penunjang/dosen/ } \\
\{\text { dosenId }\} / \text { tahun-ajar/ }\{\text { tahunAjar }\} / \\
\text { kesimpulan/penelitian }\end{array}$ & GET \\
\hline 21 & $\begin{array}{l}\text { /api/v1/bkd/penunjang/dosen/ } \\
\{\text { dosenId }\} / \text { tahun-ajar/ }\{\text { tahunAjar }\} / \\
\text { kesimpulan/pengabdian }\end{array}$ & GET \\
\hline 22 & $\begin{array}{l}\text { /api/v1/bkd/penunjang/dosen/ } \\
\{\text { dosenId }\} / \text { tahun-ajar/ }\{\text { tahunAjar }\} / \\
\text { kesimpulan/penunjang }\end{array}$ & GET \\
\hline 23 & $\begin{array}{l}\text { /api/v1/bkd/penunjang/dosen/ } \\
\{\text { dosenId } / \text { tahun-ajar/ }\{\text { tahunAjar }\} \\
\text { kesimpulan/lebihan/pendidikan }\end{array}$ & GET \\
\hline 24 & $\begin{array}{l}\text { /api/v1/bkd/penunjang/dosen/ } \\
\{\text { dosenId }\} / \text { tahun-ajar/ }\{\text { tahunAjar }\} \\
\text { kesimpulan/lebihan/penelitian }\end{array}$ & GET \\
\hline 25 & $\begin{array}{l}\text { /api/v1/bkd/penunjang/dosen/ } \\
\{\text { dosenId } / \text { tahun-ajar/ \{tahunAjar }\} \\
\text { kesimpulan/lebihan/pengabdian }\end{array}$ & GET \\
\hline 26 & $\begin{array}{l}\text { /api/v1/bkd/penunjang/dosen/ } \\
\{\text { dosenId } / \text { tahun-ajar/ \{tahunAjar }\} / \\
\text { kesimpulan/lebihan/penunjang }\end{array}$ & GET \\
\hline
\end{tabular}

TABEL V

RANCANGAN MICROSERVICES KARYA ILMIAH

\begin{tabular}{|c|c|c|}
\hline No & URI & Method HTTP \\
\hline 1 & $\begin{array}{l}\text { /api/v1/karya-ilmiah/dosen/ } \\
\{\text { dosenId }\} / \text { tahun-ajar/ }\{\text { tahunAjar }\}\end{array}$ & $\begin{array}{l}\text { GET, POST, } \\
\text { PUT, DELETE }\end{array}$ \\
\hline 2 & $\begin{array}{l}\text { /api/v1/karya-ilmiah/dosen/ } \\
\{\text { dosenId }\} \text { /tahun-ajar/ \{tahunAjar }\} \\
\text { id / } / \text { karyallmiahId }\end{array}$ & $\begin{array}{l}\text { GET, PUT, } \\
\text { DELETE }\end{array}$ \\
\hline
\end{tabular}

TABEL VI

RANCANGAN MICROSERVICES LAPORAN

\begin{tabular}{|c|l|l|}
\hline No & URI & Method HTTP \\
\hline 3 & $\begin{array}{l}\text { /api/v1/laporan/bkd/ tahun-ajar / } \\
\text { \{tahunAjar }\}\end{array}$ & GET \\
\hline
\end{tabular}

I W. A. J. Pawana: Identifikasi Kandidat Microservies Dengan. . .

p-ISSN:1693 - 2951; e-ISSN: 2503-2372 


\begin{tabular}{|c|l|l|}
\hline 4 & $\begin{array}{l}\text { /api/v1/laporan/dosen/ tahun-ajar / } \\
\text { tahunAjar }\end{array}$ & GET \\
\hline 5 & $\begin{array}{l}\text { /api/v1/laporan/remunerasi-gaji/ } \\
\text { tahun-ajar/ } \text { tahunAjar }\end{array}$ & GET \\
\hline 6 & $\begin{array}{l}\text { /api/v1/laporan/remunerasi-kinerja/ } \\
\text { tahun-ajar/ } \text { tahunAjar }\end{array}$ & GET \\
\hline
\end{tabular}

TABEL VII

RANCANGAN MICROSERVICES REMUNERASI

\begin{tabular}{|c|c|c|}
\hline No & URI & Method HTTP \\
\hline 1 & $\begin{array}{l}\text { /api/v1/remunerasi/remunerasi-gaji/ } \\
\text { tahun-ajar / \{tahunAjar\} / bulan / } \\
\text { \{bulan\} }\end{array}$ & GET \\
\hline 2 & $\begin{array}{l}\text { /api/v1/remunerasi/remunerasi-gaji/ } \\
\text { tahun-ajar / \{tahunAjar / bulan / } \\
\{\text { bulan\} / hitung }\end{array}$ & POST \\
\hline 3 & $\begin{array}{l}\text { /api/v1/remunerasi/remunerasi-gaji/ } \\
\text { tahun-ajar / }\{\text { tahunAjar }\} / \text { dosen / } \\
\text { \{dosen\} / bulan / \{bulan }\}\end{array}$ & GET \\
\hline 4 & $\begin{array}{l}\text { /api/v1/remunerasi/remunerasi- } \\
\text { kinerja/ tahun-ajar/ } \text { tahunAjar }\}\end{array}$ & GET \\
\hline 5 & $\begin{array}{l}\text { /api/v1/remunerasi/remunerasi- } \\
\text { kinerja/ tahun-ajar / \{tahunAjar }\} \text { / } \\
\text { hitung }\end{array}$ & POST \\
\hline 6 & $\begin{array}{l}\text { /api/v1/remunerasi/remunerasi- } \\
\text { kinerja/ tahun-ajar / }\{\text { tahunAjar }\} \\
\text { dosen / }\{\text { dosenId }\}\end{array}$ & GET \\
\hline 7 & $\begin{array}{l}\text { /api/v1/remunerasi/remunerasi- } \\
\text { kinerja/ tahun-ajar / \{tahunAjar }\} \text { / } \\
\text { dosen / \{dosenId }\} \text { / kegiatan-remun }\end{array}$ & GET \\
\hline 8 & $\begin{array}{l}\text { /api/v1/remunerasi/remunerasi- } \\
\text { kinerja/ tahun-ajar / \{tahunAjar\} / } \\
\text { dosen / \{dosenId\} / kegiatan- } \\
\text { nonremun }\end{array}$ & GET \\
\hline 9 & $\begin{array}{l}\text { /api/v1/remunerasi/insentif- } \\
\text { penelitian-spi/ tahun-ajar / } \\
\text { \{tahunAjar\} }\end{array}$ & GET \\
\hline 10 & $\begin{array}{l}\text { /api/v1/remunerasi/insentif- } \\
\text { penelitian-spi/ tahun-ajar / } \\
\text { \{tahunAjar\} / hitung }\end{array}$ & POST \\
\hline 11 & $\begin{array}{l}\text { /api/v1/remunerasi/insentif- } \\
\text { penelitian-spi/ tahun-ajar / } \\
\{\text { tahunAjar }\} / \text { dosen / }\{\text { dosenId }\}\end{array}$ & GET \\
\hline 12 & $\begin{array}{l}\text { /api/v1/remunerasi/insentif- } \\
\text { penelitian-spi/ tahun-ajar / } \\
\{\text { tahunAjar\} / dosen / \{dosenId } / \\
\text { kegiatan }\end{array}$ & GET \\
\hline
\end{tabular}

TABEL VIII

RANCANGAN MICROSERVICES DATA MASTER

\begin{tabular}{|c|l|l|}
\hline No & URI & Method HTTP \\
\hline 1 & /api/v1/master/tahun-ajar & $\begin{array}{l}\text { GET, POST, } \\
\text { PUT, DELETE }\end{array}$ \\
\hline 2 & $\begin{array}{l}\text { /api/v1/master/tahun-ajar/ } \\
\{\text { tahunAjar }\}\end{array}$ & $\begin{array}{l}\text { GET, PUT, } \\
\text { DELETE }\end{array}$ \\
\hline 3 & $/$ api/v1/master/kegiatan & $\begin{array}{l}\text { GET, POST, } \\
\text { PUT, DELETE }\end{array}$ \\
\hline 4 & /api/v1/master/kegiatan/ \{kegiatanId $\}$ & $\begin{array}{l}\text { GET, PUT, } \\
\text { DELETE }\end{array}$ \\
\hline 5 & $/$ api/v1/master/unit & $\begin{array}{l}\text { GET, POST, } \\
\text { PUT, DELETE }\end{array}$ \\
\hline
\end{tabular}

\begin{tabular}{|c|c|c|}
\hline 6 & /api/v1/master/unit/ \{unitId\} & $\begin{array}{l}\text { GET, PUT, } \\
\text { DELETE }\end{array}$ \\
\hline 7 & /api/v1/master/sunit & $\begin{array}{l}\text { GET, POST, } \\
\text { PUT, DELETE }\end{array}$ \\
\hline 8 & /api/v1/master/sunit/ $\{$ sunitId $\}$ & $\begin{array}{l}\text { GET, PUT, } \\
\text { DELETE }\end{array}$ \\
\hline
\end{tabular}

TABEL IX

RANCANGAN MICROSERVICES PENGAJUAN ANGKA KREDIT (PAK)

\begin{tabular}{|c|c|c|}
\hline No & URI & Method HTTP \\
\hline 1 & $\begin{array}{l}\text { /api/v1/pak/pendidikan/dosen/ } \\
\{\text { dosenId } / \text { tahun-ajar / }\{\text { tahunAjar }\end{array}$ & $\begin{array}{l}\text { GET, POST, } \\
\text { PUT, DELETE }\end{array}$ \\
\hline 2 & $\begin{array}{l}\text { /api/v1/pak/pendidikan/dosen/ } \\
\text { \{dosenId } / \text { tahun-ajar / \{tahunAjar } / \\
\text { id / } \text { / pakPendidikanId }\}\end{array}$ & $\begin{array}{l}\text { GET, PUT, } \\
\text { DELETE }\end{array}$ \\
\hline 3 & $\begin{array}{l}\text { /api/v1/pak/penelitian/dosen/ } \\
\{\text { dosenId } / \text { tahun-ajar / }\{\text { tahunAjar }\}\end{array}$ & $\begin{array}{l}\text { GET, POST, } \\
\text { PUT, DELETE }\end{array}$ \\
\hline 4 & $\begin{array}{l}\text { /api/v1/pak/penelitian/dosen/ } \\
\{\text { dosenId } / \text { tahun-ajar / }\{\text { tahunAjar }\} / \\
\text { id / } \text { pakPenelitianId }\}\end{array}$ & $\begin{array}{l}\text { GET, PUT, } \\
\text { DELETE }\end{array}$ \\
\hline 5 & $\begin{array}{l}\text { /api/v1/pak/pengabdian/dosen/ } \\
\text { \{dosenId } / \text { tahun-ajar / \{tahunAjar }\end{array}$ & $\begin{array}{l}\text { GET, POST, } \\
\text { PUT, DELETE }\end{array}$ \\
\hline 6 & $\begin{array}{l}\text { /api/v1/pak/pengabdian/dosen/ } \\
\{\text { dosenId }\} / \text { tahun-ajar / }\{\text { tahunAjar }\} / \\
\text { id / } \text { / pakPengabdianId }\}\end{array}$ & $\begin{array}{l}\text { GET, PUT, } \\
\text { DELETE }\end{array}$ \\
\hline 7 & $\begin{array}{l}\text { /api/v1/pak/penunjang/dosen/ } \\
\{\text { dosenId }\} / \text { tahun-ajar / }\{\text { tahunAjar }\}\end{array}$ & $\begin{array}{l}\text { GET, POST, } \\
\text { PUT, DELETE }\end{array}$ \\
\hline 8 & $\begin{array}{l}\text { /api/v1/pak/penunjang/dosen/ } \\
\{\text { dosenId } / \text { tahun-ajar / }\{\text { tahunAjar }\} / \\
\text { id / } \text { /pakPenunjangId }\}\end{array}$ & $\begin{array}{l}\text { GET, PUT, } \\
\text { DELETE }\end{array}$ \\
\hline 9 & $\begin{array}{l}\text { /api/v1/pak/ dosen / }\{\text { dosenId }\} / \\
\text { tahun-ajar / }\{\text { tahunAjar }\} / \text { laporan }\end{array}$ & $\begin{array}{l}\text { GET, POST, } \\
\text { PUT, DELETE }\end{array}$ \\
\hline
\end{tabular}

TABEL X

RANCANGAN MICROSERVICES SKP

\begin{tabular}{|c|l|l|}
\hline No & URI & Method HTTP \\
\hline 1 & $\begin{array}{l}\text { /api/v1/skp/ dosen / }\{\text { dosenId }\} / \\
\text { tahun-ajar/ }\{\text { tahunAjar }\} / \text { target }\end{array}$ & GET, POST, \\
\hline 2 & $\begin{array}{l}\text { PUpi/v1/skp/ dosen / DELETE } \\
\text { tahun-ajar/ }\{\text { tahunAjar }\} / \text { realisasi }\end{array}$ & GET, POST, \\
\hline
\end{tabular}

Struktur Uniform Resource Identifier (URI) pada rancangan API SIMDOSEN mengikuti kesepakatan [17] untuk meningkatkan kemampuan discoverability dan memastikan konsistensi dalam microservices.

Setelah melakukan identifikasi, dibuat dokumentasi API berdasarkan OpenAPI Specification. Hal ini bertujuan untuk membuat suatu dokumentasi yang lengkap, terpadu, dan jelas agar tidak terjadi perbedaan interpretasi antara pengembang dalam hal ini desainer, developer, tester dan devops. Selain itu pengembangan akan lebih cepat karena pengembang atau komputer dapat mengerti kemampuan dari suatu service tanpa harus mengakses source code langsung. Gambar 5 menujukkan hasil dari dokumentasi API mengunakan OpenAPI Specification untuk service dosen. 


\begin{tabular}{|c|c|c|}
\hline HTTPS & $\sim$ & Authorize 2 \\
\hline dosen & & $\wedge$ \\
\hline GET & /dosen Mendapatkan data seluruh dosen & $\checkmark 2$ \\
\hline POST & /dosen Membuat data dosen baru & $\vee 2$ \\
\hline PUT & /dosen Mongupdate data dosen socera masal & $\checkmark 2$ \\
\hline DELETE & /dosen Menghapus seluruh data dosen & $\checkmark 2$ \\
\hline CET & /dosen $/\{$ dosenId $\}$ Mendapatkan data dosen berdasarkan ID & $\vee 2$ \\
\hline PUT & /dosen/\{dosenId\} Mengupdate data dosen bedasarkan ID & $\checkmark 2$ \\
\hline DELETE & /dosen/\{dosenId $\}$ Menghapus data dosen & $v ?$ \\
\hline
\end{tabular}

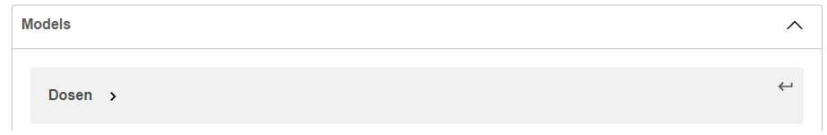

Gambar 5: Dokumentasi microservice dosen dengan OpenAPI 3 Spesification

\section{KESIMPULAN DAN SARAN}

Domain driven design memberikan konsep dan langkah untuk membangun aplikasi berbasis arsitektur microservices. Domain driven design berfokus pada domain, termasuk konsep, hubungan antar domain dan business logic. Arsitektur microservices adalah tentang bagaimana mengatur dan membagi perangkat lunak menjadi blok bangunan kecil yang terdistribusi.

Hasil penelitian ini menunjukkan, dengan pendekatan Domain Driven Design, proses migrasi arsitektur monolithic menjadi arsitektur microservice berhasil dilakukan dan menghasilkan 29 microservice dan 89 API. Pada arsitektur microservice setiap microservice memiliki database tersendiri untuk memastikan perubahan suatu microservice tidak berdampak pada microservice lain.

Keuntungan dari menggunakan DDD dan microservices adalah kemampuan untuk menggunakan kembali (reuse) fungsi yang sudah ada. Informasi hasil identifikasi model dan fungsionalitas domain dapat digunakan oleh aplikasi lain di lingkungan Universitas Udayana.

Adanya RESTful API dengan standar OpenAPI Specification 3, menyebabkan integrasi dengan pengembang lain akan menjadi lebih mudah karena pengembang lain dapat melihat dokumentasi API yang disediakan, dan dapat melihat contoh response yang diberikan tanpa perlu mengetahui source code dan struktur database dari SIMDOSEN. Hal ini akan mengurangi terjadinya perbedaan pemahaman service tim pengembang.

Harapan dari penelitian ini adalah memberikan insight kepada pengembang lain yang melakukan migrasi aplikasi monolithic menjadi arsitektur microservice. Rencana penelitian ke depan dari hasil ini adalah untuk melakukan pengembangan cloud-native di Universitas Udayana.

I W. A. J. Pawana: Identifikasi Kandidat Microservies Dengan. . .

\section{REFERENSI}

[1] J. Kazanavičius and D. Mažeika, "Migrating Legacy Software to Microservices Architecture," 2019 Open Conference of Electrical, Electronic and Information Sciences (eStream), pp. 1-5, 2019.

[2] S. Baškarada, V. Nguyen, A. Koronios. "Architecting Microservices: Practical Opportunities and Challenges." Journal of Computer Information Systems, pp. 1-9, 2018

[3] R. Chen, S. Li and Z. Li, "From Monolith to Microservices: A DataflowDriven Approach," 24th Asia-Pacific Software Engineering Conference (APSEC), pp. 466-475, 2017

[4] Martin Fowler (2014) Microservices. [Online]. Available: https://martinfowler.com/articles/microservices.html

[5] B. Butzin, F. Golatowski and D. Timmermann, "Microservices approach for the internet of things," IEEE 21 st International Conference on Emerging Technologies and Factory Automation (ETFA), pp. 1-6, 2016.

[6] N. Dragoni, S. Giallorenzo, A. L. Lafuente, M. Mazzara, F. Montesi, R. Mustan, L. Sana, "Microservices: yesterday, today, and tomorrow", Present and Ulterior Software Engineering, pp 195-216, 2017.

[7] (2021) OpenAPI Specification. [Online]. Available: https://swagger.io/specification/

[8] S. Newman, Building Microservices: Designing Fine-Grained Systems. 1st ed. O'Reilly Media, 2015.

[9] S. Karlsson, A. Čaušević and D. Sundmark, "QuickREST: Propertybased Test Generation of OpenAPI-Described RESTful APIs," IEEE 13th International Conference on Software Testing, Validation and Verification (ICST), pp. 131-141, 2020.

[10] A. Sill, "The Design and Architecture of Microservices," IEEE Cloud Computing, vol. 3, no. 5, pp. 76-80, 2016

[11] R. Fielding, J. Gettys, J. Mogul, H. Frystyk, L. Masinter, P. Leach, and T. Berners-Lee. Hypertext Transfer Protocol - HTTP/1.1. Technical Report RFC 2616, The Internet Society, http://www.ietf.org/rfe/rfc2616.txt, 1999.

[12] R. Fielding. Architectural Styles and the Design of Network-based Software Architectures. Ph.d. dissertation, University of California, Irvine, 2007.

[13] C. Pautasso. Restful web services: principles, patterns, emerging technologies. In Web Services Foundations, pages 31-51. Springer, 2014.

[14] D. Jacobson, G. Brail, D. Woods, APIs: A Strategy Guide. O'Reilly Media, Inc., 2011.

[15] M. Gebhart, P. Giessler, S. Abeck, "Challenges of the Digital Transformation in Software Engineering," ICSEA 2016: The Eleventh International Conference on Software Engineering Advances, 2016, pp. 136-141.

[16] D. M. Rathod, S. M. Parikh, B. V. Buddhadev, "Structural and Behavioral Modeling of RESTful Web Service Interface Using UML," International Conference on Intelligent Systems and Signal Processing (ISSP), March 2013, pp. 28-33.

[17] P. Giessler, M. Gebhart, D. Sarancin, R. Steinegger, S. Abeck, "Best Practices for the Design of RESTful Web Services," International Conferences of Software Advances (ICSEA), 2015.

[18] B. Hippchen, P. Giessler, R. Steinegger, M. Schneider, S. Abeck, "Designing Microservice-Based Applications by Using a Domain Driven Design Approach," International Journal on Advances in Software, Vol. 10, No. 3\&4, pp. 432-445, 2017.

[19] V. Vaugh, Implementing Domain-Driven Design, Addison-Wesley Professional, 2013.

[20] C. Y. Fan, S. P. Ma, "Migrating Monolithic Mobile Application to Microservice Architecture: An Experiment Report," IEEE 6th International Conference on AI and Mobile Services, p. 109-112, 2017.

[21] I. W. Len Bass and L. Zhu, DevOps: A Software Architect's Perspective. Addison-Wesley Professional, 2015.

[22] Evans, Eric, Domain-driven design: tackling complexity in the heart of software, Addison-Wesley, 2004.

[23] Martin Fowler (2014) DomainDrivenDesign. [Online]. Available: https://martinfowler.com/bliki/DomainDrivenDesign.html

[24] Martin Fowler (2014) BoundedContext. [Online]. Available: https://martinfowler.com/bliki/BoundedContext.html

p-ISSN:1693 - 2951; e-ISSN: 2503-2372 
[25] P. D. Francesco, I. Malavolta and P. Lago, "Research on Architecting Microservices: Trends, Focus, and Potential for Industrial Adoption," IEEE International Conference on Software Architecture (ICSA), pp. 21-30, 2017.

[26] Y. Gan and C. Delimitrou, "The Architectural Implications of Cloud Microservices," IEEE Computer Architecture Letters, vol. 17, no. 2, pp. 155-158, 2018.

[27] K. Kurniawan, N. Putra Sastra, and M. Sudarma, "Analisis Performansi Dan Efisiensi Cloud Computing Pada Sistem Perbankan", Majalah Ilmiah Teknologi Elektro, vol 19, no 1, pp 11-18, Oct. 2020. 